GRASAS Y ACEITES 66 (3)

July-September 2015, e088

ISSN-L: 0017-3495

doi: http://dx.doi.org/10.3989/gya.1180142

\title{
Optimization of oligoglycerol fatty acid esters preparation catalyzed by Lipozyme 435
}

\author{
F.L. Wan, Y.L. Teng, Y. Wang ${ }^{凶}$, A.J. Li and N. Zhang \\ Guangdong Saskatchewan Oilseed Joint Laboratory, Guangdong Engineering Technology Research Center for Oils and Fats \\ Biorefinery, Department of Food Science and Engineering, Jinan University, GuangZhou 510632, China \\ ${ }^{\square}$ Corresponding author: twyong@jnu.edu.cn
}

Submitted: 5 November 2014; Accepted: 12 February 2015

\begin{abstract}
Oligoglycerol fatty acid esters (OGEs) are an important kind of polyglycerol fatty acid esters (PGEs) which have been widely used as emulsifiers in food, medicine and cosmetic industries. The aim of this study was to investigate the preparation of OGEs by the esterification of oligoglycerol with linoleic acid in a solvent-free system using Lipozyme 435 as the catalyst. The effects of substrate molar ratio, reaction time, reaction temperature, enzyme dosage, and water addition on the efficiency of esterification (EE) were studied. Single factor experiments and response surface methodology (RSM) were employed to optimize the reaction parameters. The optimum conditions were obtained as follows: reaction time $4.52 \mathrm{~h}$, reaction temperature $90{ }^{\circ} \mathrm{C}$, enzyme dosage $2 \mathrm{wt} \%$ (based on the total substrate mass), the molar ratio of oligoglycerol to linoleic acid 1.59:1 and no water addition. Under these conditions, the experimental EE $(95.82 \pm 0.22 \%)$ fitted well with that predicted by RSM (96.15\%). Similar results were obtained when the process was scaled up to a production of $500 \mathrm{~g}$ in a pilot bubble column reactor (BCR). The enzyme maintained $98.2 \%$ of the relative activity after 10 batches of reaction in the BCR. Electrospray ionization mass spectrum was employed to rapidly analyze the esterification products, and most species of OGEs have been identified.
\end{abstract}

KEYWORDS: Biocatalysis; Bubble column reactor; Esterification; Immobilized enzyme; Lipase; Oligoglycerol fatty acid esters

RESUMEN: Optimización de la preparación de ésteres grasos de oligoglicerol catalizada por Lipozyme 435. Los ésteres grasos de oligoglicerol (OGEs) son una clase importante de ésteres de ácidos grasos de poliglicerol (PGE) que han sido ampliamente utilizados como emulsionantes en alimentación, medicina y en la industria cosmética. El objetivo de este estudio fue investigar la preparación de OGEs mediante la esterificación de oligoglicerol con ácido linoleico en un sistema libre de disolvente utilizando Lipozyme 435 como catalizador. Se estudiaron los efectos en la eficiencia de esterificación (EE) de la relación molar de sustratos, de los tiempos de reacción, las temperaturas de reacción, la dosis de la enzima, y de la adición de agua. Se realizaron ensayos factoriales individuales y metodología de superficie de respuesta (RSM) para optimizar los parámetros de la reacción. Las condiciones óptimas se obtuvieron como sigue: tiempo de reacción $4,52 \mathrm{~h}$, temperatura de reacción $90{ }^{\circ} \mathrm{C}$, dosis de enzima $2 \%$ en peso (basado en la masa total del sustrato), la relación molar de ácido linoleico:oligoglicerol fue de 1,59:1 sin adición de agua. Bajo estas condiciones, el EE experimental (95,82 $\pm 0,22 \%)$ se corresponde bien con lo predicho mediante RSM $(96,15 \%)$. Se obtiene un resultado similar cuando el proceso se escaló a una producción piloto de hasta $500 \mathrm{~g}$ en un reactor de columna de burbujas (BCR). La enzima mantiene el 98,2\% de su actividad relativa después de 10 lotes de reacción en el BCR. Se empleó un espectrómetro de masas de ionización mediante electrospray para analizar rápidamente los productos de esterificación, y se han identificado la mayoría de las especies de OGEs. 
PALABRAS CLAVE: Biocatálisis; Enzima inmovilizada; Ésteres grasos de oligoglicerol; Esterificación; Lipasa; Reactor de columna de burbujas

Citation/Cómo citar este artículo: Wan FL, Teng YL, Wang Y, Li AJ, Zhang N. 2015. Optimization of oligoglycerol fatty acid esters preparation catalyzed by Lipozyme 435. Grasas Aceites 66 (3): e088. doi: http://dx.doi.org/10.3989/ gya.1180142.

Copyright: (C) 2015 CSIC. This is an open-access article distributed under the terms of the Creative Commons Attribution-Non Commercial (by-nc) Spain 3.0 Licence.

\section{INTRODUCTION}

Natural fats and oils are attractive feed stocks for the chemical industry as they are renewable and more eco-friendly compared with fossil resources. This makes it very interesting for them to be manufactured into surfactants. Polyglycerol fatty acid esters (PGEs) are one such new type of safe and effective non-ionic surfactant, with extensive applications in food, cosmetic, detergents, and pharmaceuticals (Richardson et al., 2004, Shima et al., 2004, Takatori et al., 2004). PGEs are amphiphilic molecules which show good properties for emulsification, crystallization adjustment, viscosity modifier, moisturizing, antimicrobial, etc. Their amphiphilic nature makes them suitable to be used for the stabilization of food emulsion (Curschellas et al., 2013) and reverse microemulsion (Ding et al., 2007). Recently, PGEs have been used as a crystal inhibitor to retard precipitation in the diacylglycerol-rich oil (Saitou et al., 2014). Since PGEs have a higher content of hydroxyl groups, their emulsifying properties are considered to be superior to that of monoglycerides (Yamagata et al., 2000).

According to Griffin (1954), the emulsifying properties of esters depend on their hydrophilic lipophilic balance (HLB) values; a higher HLB value indicates a higher hydrophilicity. To meet different applications, PGE products with different HLB values (2 to 16) can be prepared by changing the degree of polymerization (n), the degree of esterification and the chain length of fatty acids (Márquez-Alvarez et al., 2004). Oligoglycerols (di- and/or triglycerol, $\mathrm{n}=2$ or 3 ) are more hydrophilic than higher ones $(n \geq 4)$ therefore have higher solubility in polar solvents. With the increase in $\mathrm{n}$, the viscosity of polyglycerol increases with its color changing from white to deep yellow (Martin and Richter, 2011). Oligoglycerols are considered to have more promising applications than high polyglycerol $(n \geq 4)$. Among PGEs, oligoglycerol fatty acid esters (OGEs) are of great importance due to their outstanding emulsifying properties (Márquez-Álvarez et al., 2004).

PGEs can be prepared either chemically or enzymatically. The enzymatic method is preferred as enzymes are generally more specific, react under mild conditions, and produce less side products (Panpipat et al., 2012, Blasi et al., 2007). The lipase-catalyzed synthesis of PGEs through the esterification or transesterification of polyglycerol with fatty acids or methyl esters has been studied thoroughly (Ortega et al., 2014, Ortega et al., 2013, Xiao et al., 2012, Charlemagne and Legoy, 1995). All of these processes are solvent-free systems. These processes are regarded as greener alternatives to those using organic solvents, as the latter may leave undesirable solvent residues in food products. However, so far the synthesis of OGEs by lipase with oligoglycerols as substrate has received little attention, and the optimal condition for the industrial preparation of OGEs has not been reported. This undoubtedly hindered the application of OGEs. Therefore, in this study, determination of the optimal conditions for the enzymatic synthesis of OGEs is included.

Lipozyme 435 is a commercially available immobilized lipase from Candida antarctica with high activity, operational stabilities and stereospecificity. This lipase is highly robust and presents activity under a wide variety of conditions so it has enormous importance for hydrolysis and synthesis reactions (Ortega et al., 2014). Thus, it has been extensively used as a biocatalyst to catalyze esterification reactions (Duan et al., 2013, Souza et al., 2009).

In this study, Lipozyme 435 was utilized to catalyze the esterification of oligoglycerol with linoleic acid in the solvent-free system to prepare OGEs. The effects of reaction conditions investigated include reaction temperature, reaction time, substrate molar ratio, enzyme dosage and water content. Single factor experiments and response surface methodology (RSM) were used to optimize the process at a laboratory scale. Usually, the optimized conditions obtained by RSM are only valid under the experimental setting where the optimization was performed. Here the possibility of using the lab-scale optimum conditions in a pilot-scale plant setting was attempted to study the potential of the enzymatic reaction in industrial application. So the lab-scale-optimized conditions were transferred to pilot-scale in a bubble column reactor (BCR) (Mollenhauer et al., 2010). The operational stability of Lipozyme 435 under pilot-scale conditions was also investigated by reusing it in the BCR. Electrospray ionization mass spectrum (ESI-MS) which was considered as a quick and convenient tool for a qualitative analysis was employed to analyze the composition of esterification products (Khemchyan et al., 2013). 


\section{MATERIALS AND METHODS}

\subsection{Chemicals}

Linoleic acid (95\%) was purchased from Anqing biological engineering Co., Ltd. (Anhui, China). Lipozyme 435 (formerly named Novozym ${ }^{\circledR} 435$ before 2010, declared activity 10000 PLU/g) was obtained from Novozymes A/S (Bagsvaerd, Denmark). Sodium hydroxide and glycerol were purchased from Fuyu chemical Co. Ltd. (Tianjin, China). Acetone and methanol were brought from MREDA technology Inc. (USA). All chemicals were of pure, analytical grade, and all solvents used were of HPLC grade.

\subsection{Preparation and purification of oligoglycerols}

Glycerol (150.0 g) and sodium hydroxide (5.25 g, $3.5 \mathrm{wt} \%$ based on the glycerol) were added to a $250 \mathrm{~mL}$ three-neck flask equipped with a condenser. The reaction was performed under nitrogen to prevent the dehydration of glycerol to acrolein. The mixture was reacted for $3.5 \mathrm{~h}$ at $250^{\circ} \mathrm{C}$ and $400 \mathrm{rpm}$. After reaction, it was cooled down to room temperature, and the crude oligoglycerols were purified using molecular distillation (MD). The glycerol was removed and the heavy phase was collected under the following conditions: evaporator temperature $120{ }^{\circ} \mathrm{C}$, condenser temperature $50{ }^{\circ} \mathrm{C}$, evaporator vacuum pressure $5.0 \mathrm{~Pa}$, and roller speed $300 \mathrm{rpm}$. The high polyglycerol $(n \geq 4)$ removed from the heavy phase of MD has been collected, and the light phase containing oligoglycerols was obtained using the following conditions: evaporator temperature $170{ }^{\circ} \mathrm{C}$, condenser temperature $60{ }^{\circ} \mathrm{C}$, evaporator vacuum pressure 1.0 $\mathrm{Pa}$, and roller speed $300 \mathrm{rpm}$.

\subsection{Analysis of the oligoglycerol composition by gas chromatography (GC)}

The composition of oligoglycerols was analyzed by gas chromatography (GC) according to a modified method described by Xiao et al. (2012). The GC analysis was carried out on an Agilent GC 7820A instrument (Agilent Technologies Inc., America), equipped with a flame ionization detector (FID) and a capillary column of AT-Wax $(15 \mathrm{~m} \times 0.32 \mathrm{~mm}, 0.25 \mu \mathrm{m})$. The injector temperature was $280{ }^{\circ} \mathrm{C}$ and was used in the split mode with a split ratio of 20:1. FID was kept at $280{ }^{\circ} \mathrm{C}$ and the flow rate of the carrier gas $\left(\mathrm{N}_{2}\right)$ was kept at $30 \mathrm{~mL} \cdot \mathrm{min}^{-1}$. In each measurement, $1 \mu \mathrm{L}$ of sample was injected. The oven temperature was programmed from $120^{\circ} \mathrm{C}$ to $260^{\circ} \mathrm{C}$ as follows: rising from $120^{\circ} \mathrm{C}$ to $165^{\circ} \mathrm{C}$ at a rate of $60{ }^{\circ} \mathrm{C} \cdot \mathrm{min}^{-1}$ and held for $4 \mathrm{~min}$, to $230^{\circ} \mathrm{C}$ at a rate of $60^{\circ} \mathrm{C} \cdot \mathrm{min}^{-1}$ and held for $2 \mathrm{~min}$, to $260^{\circ} \mathrm{C}$ at a rate of $10^{\circ} \mathrm{C} \cdot \mathrm{min}^{-1}$ and held for $3 \mathrm{~min}$. The percentage content of each oligoglycerol was calculated assuming the same response factor and the results are shown in Table 1.
TABLE 1. Composition (means \pm SD) of oligoglycerols after purification by molecular distillation. ${ }^{\mathrm{a}}$

\begin{tabular}{lc}
\hline Component & Percent $(\mathbf{w t} \%)$ \\
\hline Glycerol & $0.54 \pm 0.06$ \\
PG2 & $62.22 \pm 2.67$ \\
PG3 & $32.83 \pm 1.91$ \\
PG4 & $4.41 \pm 0.74$ \\
\hline
\end{tabular}

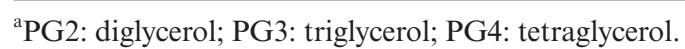

\subsection{Lipase-catalyzed synthesis of OGEs in a solvent free system}

Enzymatic esterification was carried out in a solvent-free system. Lipozyme 435, oligoglycerols and linoleic acid were added to a $25 \mathrm{~mL}$ airtight flask and reacted at $300 \mathrm{rpm}$ under vacuum conditions $(4 \mathrm{kPa})$ to remove water and avoid the oxidation of the reagents. The effects of different molar ratio of oligoglycerol to linoleic acid (2:1 1:2), enzyme dosage $(0.5 \sim 3.0 \mathrm{wt} \%$ of the total substrate mass), reaction temperature $\left(60 \sim 120{ }^{\circ} \mathrm{C}\right)$, reaction time $(2 \sim 6 \mathrm{~h})$, and water addition $(0 \sim 12 \mathrm{wt} \%$ of the total substrate mass) on the EE were studied.

At the end of each reaction, $8 \mathrm{~mL}$ of reaction mixture were taken and centrifuged at $3000 \mathrm{rpm}$ for $10 \mathrm{~min}$ to be separated into three layers. The immobilized enzyme was present in the middle level. It can be isolated by filtration and used repeatedly. The upper oil phase was titrated with a $0.1 \mathrm{M}$ $\mathrm{NaOH}$ standard solution using phenolphthalein as the endpoint indicator to obtain the acid value. The EE of the reaction was calculated according to the following formula:

$\mathrm{EE}(\%)=\frac{A V_{0}-A V}{A V_{0}} \times 100$

Where $A V_{0}$ is the acid value of linoleic acid, and $A V$ is the acid value of the upper oil phase. All determinations were carried out in duplicate and the average values were reported.

\subsection{Determination of optimal reaction conditions by RSM}

To achieve maximal EE, a three-level three-factor Box-Behnken design was adopted to optimize the reaction conditions. The factors studied were enzyme dosage $\left(E_{d}, w t \%\right)$, the molar ratio of substrate $\left(S_{r}\right.$, $\mathrm{mol} / \mathrm{mol})$ and the reaction time $\left(\mathrm{T}_{\mathrm{i}}, \mathrm{h}\right)$. The response studied was the efficiency of esterification (EE, \%). The ranges of settings for factors were based on the results of single factor experiments and shown in Table 2. The initial reaction temperature was fixed at $90{ }^{\circ} \mathrm{C}$ for all experiments. All of the experiments 
TABLE 2. Independent variables and levels used in the Box-Behnken design

\begin{tabular}{lccc}
\hline & \multicolumn{3}{c}{ Levels } \\
\cline { 2 - 4 } Independent variables & $\mathbf{1}$ & $\mathbf{0}$ & $\mathbf{- 1}$ \\
\hline $\mathrm{T}_{\mathrm{i}}($ time, $\mathrm{h})$ & 5 & 4 & 3 \\
$\mathrm{~S}_{\mathrm{r}}$ (molar ratio of substrate, $\left.\mathrm{mol} / \mathrm{mol}\right)$ & 2 & 1.5 & 1 \\
$($ enzyme dosage, $\mathrm{wt} \%)$ & 2 & 1.5 & 1
\end{tabular}

were performed in triplicate and the average values were reported. Design Expert software (version 7.0, Stat-ease, Inc.) was used for the analysis of variance (ANOVA) and regression analysis of the experimental data.

\subsection{Scaling-up synthesis of OGEs in the BCR}

The scaling-up synthesis of OGEs was performed in a $2 \mathrm{~L}$ pilot-scale BCR (Figure 1) manufactured by Handway Technology Co., Ltd. (Foshan, China) and the Department of Food Science and Engineering, Jinan University (Guangzhou, China). Oligoglycerols (300.00 g), linoleic acid (267.85 g) and Lipozyme 435 $(11.36 \mathrm{~g})$ were added to the reactor vessel and reacted under the optimum conditions (as obtained from section 2.5). $\mathrm{N}_{2}$ gas was bubbled through the sieve at the bottom of the reactor where it entered into the reaction system and formed a boiling-like mixture. With this gas bubbling, the heterogeneous reaction system was vigorously agitated. Therefore the immiscible reactants and immobilized enzymes were efficiently mixed by the $\mathrm{N}_{2}$ bubbling to enhance the reaction rate. The water formed by the reaction can be efficiently removed by the $\mathrm{N}_{2}$ flow $\left(2.5 \mathrm{~L} \cdot \mathrm{min}^{-1}\right)$ and collected by the condenser. The removal of water was beneficial to shift the thermodynamic equilibrium to the esterification. The $\mathrm{N}_{2}$ gas pumped through the reactor was recycled to save on its consumption. After the reaction, the liquid reaction mixture was collected through the sieve. The immobilized enzyme was retained in the reactor, washed by anhydrous ethanol, and used for the next batch reaction under the same conditions. The product collected was centrifuged and separated into two layers. The upper layer was the OGEs phase which was analyzed by HPLC and ESI-MS.

\subsection{The reusability of Lipozyme 435 in BCR}

A distinct advantage of the $\mathrm{BCR}$ is the lower mechanical shear force which allows for maintaining a considerably longer half-life of enzyme. In this study, 10 consecutive batches of OGEs production were conducted under the optimized conditions to assess the reusability of Lipozyme 435 . The relative activity of enzyme was defined as follows:

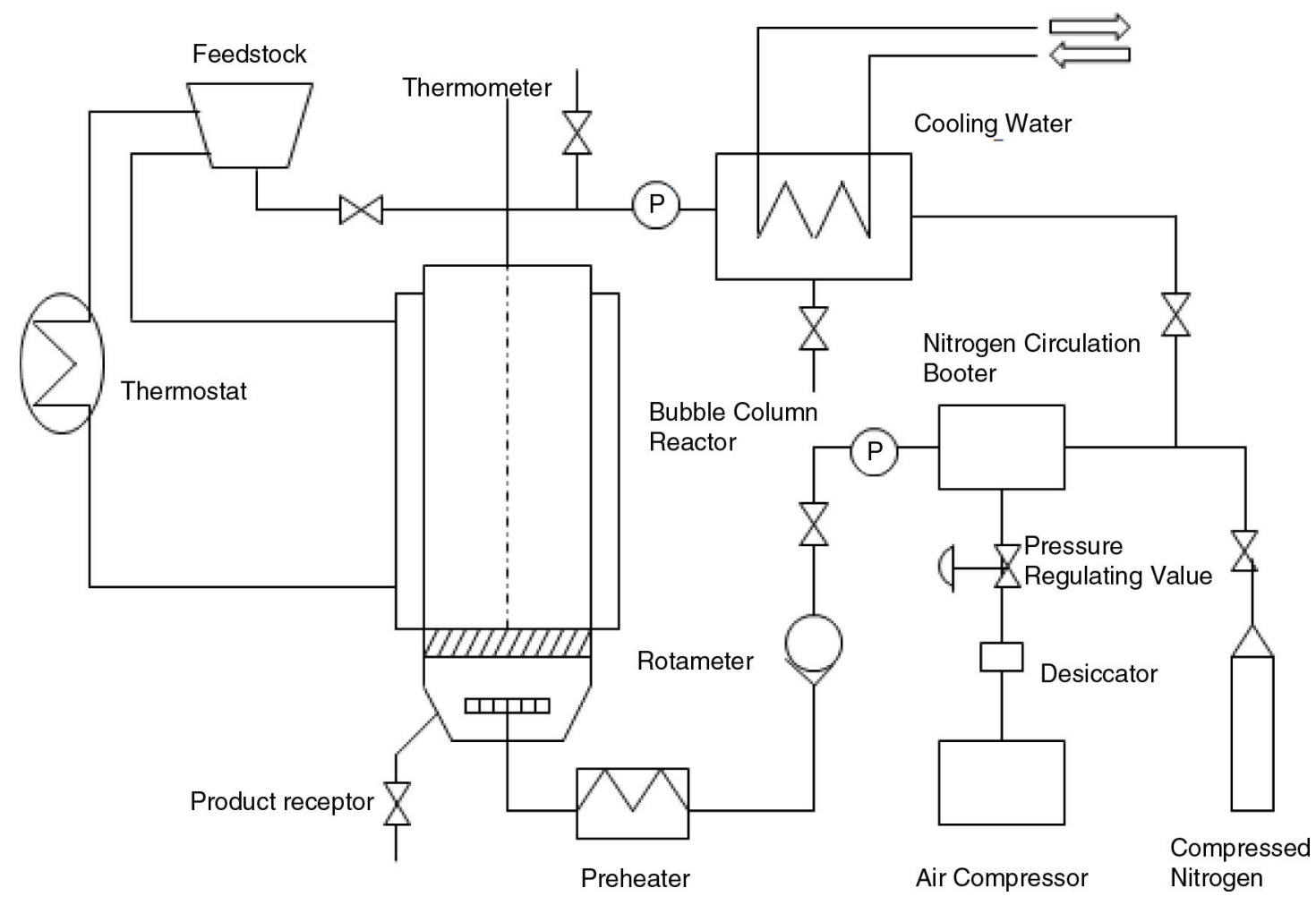

FigURE 1. Simplified flow diagram of the bubble column reactor equipment. 
Relative activity $(\%)=\frac{\text { EE of each batch }}{\text { EE of the } 1 \text { st batch }} \times 100$

\subsection{Composition of the esterification products analyzed by HPLC and ESI-MS}

High performance liquid chromatography (HPLC) and ESI-MS were employed to analyze the composition of the esterification products. The HPLC system was composed of a Shimadzu HPLC system (LC-20AD pump, SIL-20A auto injector) equipped with a $150 \mathrm{~mm} \times 4.6 \mathrm{~mm}$ Diamonsil C18(2) column (DIKMA, Beijing, China) and a Sedex 55 evaporative light scattering detector (ELSD) (SEDERE, France). The ELSD was set to $70{ }^{\circ} \mathrm{C}$ with a carrier air flow rate of $1.7 \mathrm{~L} \cdot \mathrm{min}^{-1}$. The column temperature was set to $40{ }^{\circ} \mathrm{C}$. A mixture of acetonitrile/ isopropyl alcohol $(55 / 45, \mathrm{v} / \mathrm{v})$ was delivered as the mobile phase at a flow rate of $1.0 \mathrm{~mL} \cdot \mathrm{min}^{-1}$. The samples were dissolved in isopropyl alcohol with a concentration of $5.0 \mathrm{mg} \cdot \mathrm{mL}^{-1}$. About $1 \mathrm{~mL}$ of this sample solution was filtered through a nylon membrane filter $(0.22 \mu \mathrm{m})$, transferred to a $1.5 \mathrm{~mL}$ sample vial, and analyzed by HPLC. The injection volume of each analysis was $0.5 \mu \mathrm{L}$. Each sample was analyzed twice and the average value was reported. The content of each ester compound was estimated by calculating the peak areas obtained from the ELSD chromatogram assuming the same response factors.

The MS spectrum was recorded with an $\mathrm{AB}$ 4000 QTRAP mass spectrometer (USA) equipped with an ESI source. The samples were dissolved in methanol and were delivered to the ESI source with a syringe pump at a flow rate of $10 \mu \mathrm{L} \cdot \mathrm{min}^{-1}$. The operating parameters were as follows: ions spray voltage $5500 \mathrm{~V}$, capillary voltage $40 \mathrm{~V}$, nebulizing gas pressure $30 \mathrm{psi}$, and capillary temperature $250{ }^{\circ} \mathrm{C}$. Mass spectra within a mass range of $100 \sim 2000 \mathrm{~m} / \mathrm{z}$ were acquired in the positive ion mode. The compositions of OGEs were identified by measuring their $\mathrm{m} / \mathrm{z}$ values.

\section{RESULTS AND DISCUSSION}

\subsection{Effect of reaction temperature}

The effect of reaction temperature on the $\mathrm{EE}$ was studied at the range of $60 \sim 120{ }^{\circ} \mathrm{C}$ for $5 \mathrm{~h}$ with an oligoglycerol/linoleic acid molar ratio at 1.5:1 and an enzyme dosage of $3 \mathrm{wt} \%$. As seen from the Figure 2a, The EE soared from $76.6 \%$ at $60{ }^{\circ} \mathrm{C}$ to $95.0 \%$ at $90{ }^{\circ} \mathrm{C}$ and plateaued between $90{ }^{\circ} \mathrm{C}$ and $110^{\circ} \mathrm{C}$, suggesting that the reaction temperature had a dramatic influence on the esterification reaction. This may be explained by the effect of temperature on the enzyme activity and the affinity of the enzyme for substrate (Eom et al., 2010). The appropriately elevated reaction temperature was very effective in improving the mass transfer by increasing the activity of the enzyme and the diffusion of the substrate. However, the EE declined rapidly above $110^{\circ} \mathrm{C}$, indicating that thermal deactivation of the enzyme had taken place. This deactivation was attributed to the destroying of the spatial conformation and structure of the enzyme at high temperatures.

According to the literature (Duan et al., 2013, Pan et al., 2013), the optimal reaction temperature of Lipozyme 435 is between $60 \sim 70^{\circ} \mathrm{C}$, and above $70^{\circ} \mathrm{C}$ the stability of the enzyme is reduced as a result of changing the secondary and tertiary structure of the protein. Few data are found in the literature regarding the reaction temperature at an excess of $80{ }^{\circ} \mathrm{C}$ in enzyme catalyzed reactions. Nevertheless, here the reaction was performed above $90{ }^{\circ} \mathrm{C}$, and high EEs $(>95 \%)$ were achieved. The result indicated that Lipozyme 435 is a thermostable enzyme and can react at above $90{ }^{\circ} \mathrm{C}$. This can be explained by the fact that the immobilization of the lipase makes the enzyme conformation stable and hence enhances its thermal stability. On the other hand, due to the high viscosity of oligoglycerol, it was necessary to raise the reaction temperature in order to reduce the viscosity of the reaction system and to increase the solubility of oligoglycerol in the fatty-acid phase. However, with the increase in temperature, the possibility of water-stripping from the enzyme surface was increased. So the optimal reaction temperature was selected at $90^{\circ} \mathrm{C}$ for subsequent experiments.

\subsection{Effect of reaction time}

To determine the optimal reaction time, esterification reactions with different reaction times $(2 \sim 6 \mathrm{~h})$ were conducted at $90{ }^{\circ} \mathrm{C}$ and an enzyme dosage of $3 \mathrm{wt} \%$ with an oligoglycerol/linoleic acid molar ratio of 1.5:1. As shown in Figure 2b, the EE increased from $91.90 \%$ at $2 \mathrm{~h}$ to $95.51 \%$ at $3 \mathrm{~h}$, and it did not improve significantly afterwards, indicating that the equilibrium state had been reached.

Compared to the data reported by Pan et al. (2013), although here the reaction was carried out at a lower enzyme dosage ( $3 \mathrm{wt} \%$ vs. $6.1 \mathrm{wt} \%$ ), the equilibrium was reached in a shorter time period ( $3 \mathrm{~h}$ vs. $24 \mathrm{~h})$ and the EE obtained was even higher $(95.51 \%$ vs. $92.4 \%$ ). Several reasons could explain this: (a) the esterification reaction here was carried out in a solvent-free system. This increased substrate concentrations and avoided the enzyme deactivation caused by organic solvents (e.g. methanol) which were beneficial for achieving a fast reaction rate (Shimada et al., 2002). (b) A higher reaction temperature $\left(90^{\circ} \mathrm{C}\right)$ was adopted in this study. This decreased the viscosity of the reaction mixture, improved the diffusion, and hence enhanced the accessibility of the reagents to the active-site of the enzyme. (c) It has been reported that Lipozyme 435 is more selective to fatty acids with a certain chain length and degree of 
(a)

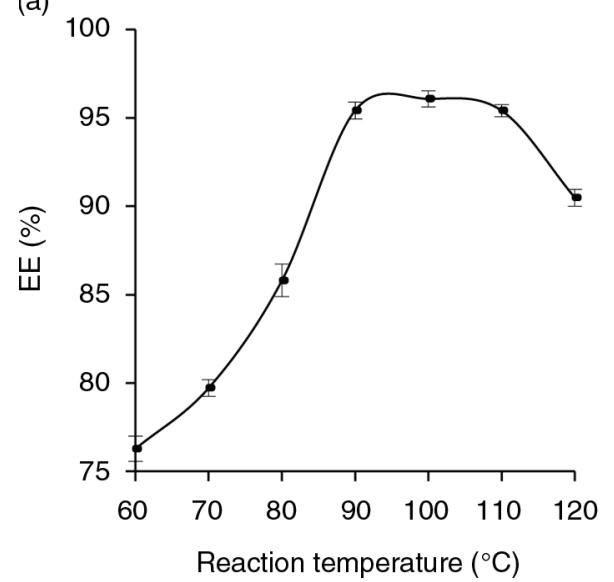

(c)

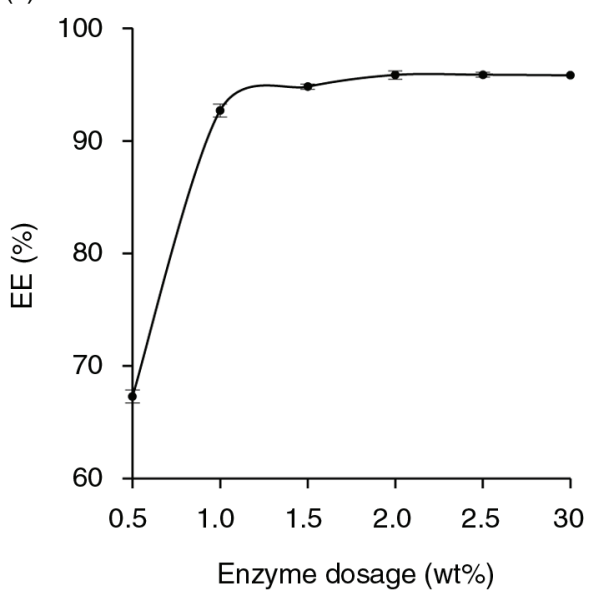

(e)

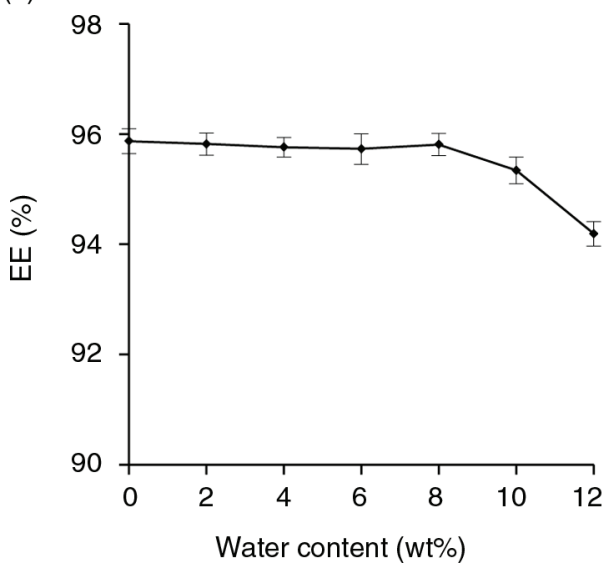

(b)

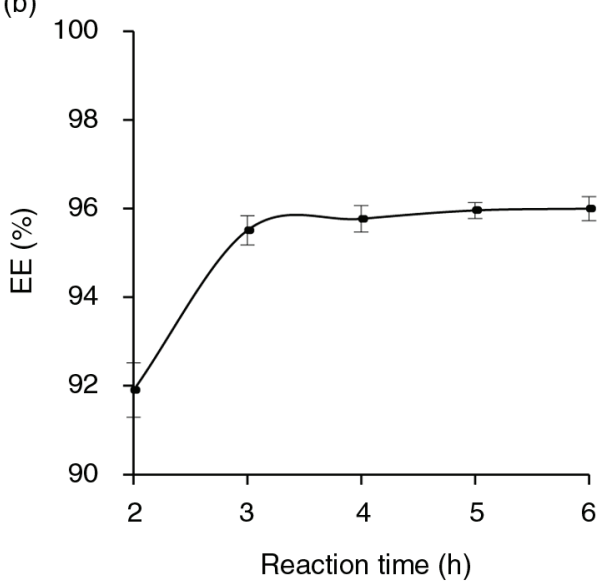

(d)

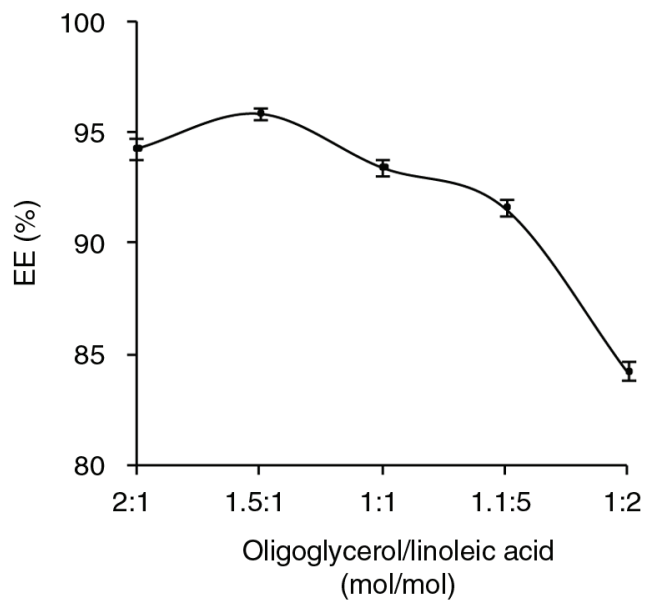

FIGURE 2. Single factor experiments of lipase-catalyzed esterification of oligoglycerol with linoleic acid. The efficiency of esterification (EE) (means $\pm \mathrm{SD}, \mathrm{n}=3$ ) was effected by: (a) Reaction temperature (oligoglycerol/linoleic acid molar ratio at 1.5:1, enzyme dosage $3 \mathrm{wt} \%$, reaction time $5 \mathrm{~h}$ ); (b) Reaction time (oligoglycerol/linoleic acid molar ratio at $1.5: 1$, enzyme dosage $3 \mathrm{wt} \%$, reaction temperature $90{ }^{\circ} \mathrm{C}$ ); (c) Enzyme dosage (oligoglycerol/linoleic acid molar ratio at 1.5 .1 , reaction temperature $90{ }^{\circ} \mathrm{C}$, reaction time $3 \mathrm{~h}$ ); (d) Mole ratio of oligoglycerol to linoleic acid (reaction temperature $90^{\circ} \mathrm{C}$, reaction time $3 \mathrm{~h}$, enzyme dosage $2 \mathrm{wt} \%$ ); (e) Initial water content (oligoglycerol/linoleic acid molar ratio at $1.5: 1$, reaction temperature $90^{\circ} \mathrm{C}$, reaction time $3 \mathrm{~h}$, enzyme dosage $2 \mathrm{wt} \%$ ).

unsaturation (Zou and Akoh, 2013), thus it might be possible that the enzyme could show a higher activity to linoleic acid. (d) The use of vacuum conditions to avoid linoleic acid oxidation also removed the water formed by the reaction, which drove the equilibrium to form the ester products. 


\subsection{Effect of enzyme dosage}

To investigate the effect of the enzyme dosage on the EE, experiments with various enzyme dosage $(0.5 \sim 3 \mathrm{wt} \%)$ were performed for $3 \mathrm{~h}$ at $90{ }^{\circ} \mathrm{C}$ with an oligoglycerol/linoleic acid molar ratio of 1.5:1 (Figure 2c). It can be seen that the EE soared from $67.29 \%$ to $92.69 \%$ when the enzyme dosage was increased from $0.5 \mathrm{wt} \%$ to $1 \mathrm{wt} \%$, and it plateaued at $95.85 \%$ with the enzyme dosage of $2 \mathrm{wt} \%$.

Higher enzyme dosages enhanced the effective contact area between enzyme and substrate molecules and provided abundant active sites as a result of increasing the probability of substrate enzyme collision, which were conducive to the reaction occurring (Zhong et al., 2013). However, the contacting area between the enzyme and substrates reached saturation when an excessive amount of enzyme was added. It led to the incomplete exposure of the lipase to the substrates at the active site. So a further increase in the enzyme dosage had little effect on the EE. Thus, $2 \mathrm{wt} \%$ was chosen as the optimal enzyme dosage in this esterification reaction.

\subsection{Effect of oligoglycerol/linoleic acid molar ratio}

The esterification of oligoglycerol with different molar ratios of linoleic acid $(2: 1 \sim 1: 2)$ has been carried out for $3 \mathrm{~h}$ at $90{ }^{\circ} \mathrm{C}$ at the enzyme dosage of $2 \mathrm{wt} \%$. It can be seen from Fig. $2 \mathrm{~d}$ that the maximum EE $(95.87 \%)$ was obtained at a molar ratio of oligoglycerol/linoleic acid of 1.5:1.

In previous studies, the effect of glycerol/fatty acid molar ratio on acylglycerol synthesis has been reported. According to Byun et al. (2007), a large excess of glycerol could improve the yield of monoacylglycerol (MAG) $(68 \mathrm{wt} \%)$ by the esterification of fish oil fatty acids with glycerol, because the esterification equilibrium was displaced toward product formation. Brady et al. (1988) pointed out that increasing the concentration of glycerol can greatly improve enzyme stability. However, in this study, the EE was overall decreased with the increasing amount of oligoglycerol. This is possibly due to the higher viscosity of oligoglycerol compared with that of glycerol. High viscosity of the reaction mixture prevented the diffusion of substrates and hindered the removal of water formed by the esterification. As will be discussed in the next section, high amounts of water had a negative effect on EE. On the other hand, high amounts of linoleic acid also decreased EE. This might be explained by the acidification of the micro-aqueous interface of the enzyme which would inhibit the enzyme activity (Chowdary et al., 2000). Previous investigations have reported that free fatty acids had a strong inhibition effect on enzyme activity when the substrate acid concentration rose above a critical level (Duan et al., 2013). Therefore, in this research the optimal oligoglycerol/linoleic acid molar ratio was 1.5:1.

\subsection{Effect of water content}

To explore the effect of water content $(0-12 \mathrm{wt} \%$ of the substrate) on the EE, experiments were carried out under the optimum conditions established from the above discussion $\left(90^{\circ} \mathrm{C}, 3 \mathrm{~h}\right.$, oligoglycerol/ fatty acid molar ratio $1.5: 1$, enzyme dosage $2 \mathrm{wt} \%$ ). As displayed in Figure 2e, the EE had a tendency to decline with increased water content.

Theoretically, the appropriate amount of water is essential to maintaining the enzyme activity (Wang et al., 2009). However, as Lipozyme 435 is a type of immobilized lipase that already has a certain content of water, and it can maintain activity without the addition of extra water (Zhong et al., 2013). On the contrary, the addition of extra water reduced the enzyme concentration and affected the hydration of the enzyme directly, or indirectly, by changing the nature of lipase support materials (Freitas et al., 2007), which resulted in a decrease in enzyme activity. On the other hand, esterification is the reverse reaction of hydrolysis. Excessive water accumulated during the progression of the reaction is favorable for hydrolysis rather than esterification. Therefore the removal of water shifted the equilibrium toward the formation of desired products. So in this study, the vacuum condition was applied to remove water and ensure a high EE.

\subsection{Model fitting of RSM}

Based on the above individual studies, RSM using the Box-Behnken design (Table 2) was applied to obtain the optimal reaction conditions. The EE obtained from all the experiments are given in Table 3. Model fitting and ANOVA results (Table 4) show that the quadratic polynomial model was suitable $\left(\mathrm{F}\right.$-value $=84.9$ at $\left.\mathrm{p}<0.001, \mathrm{R}^{2}=0.9909\right)$ for representing the actual relationship of reaction parameters. The insignificant lack of fit test $(\mathrm{F}$-value $=0.26)$ with $p>0.05$ also indicated that the model represented the experimental data well. The coefficient of determination $\left(\mathrm{R}^{2}\right)$ and adjusted- $\mathrm{R}^{2}$ were 0.9909 and 0.9793 , respectively, suggesting that the polynomial model used was accurate. Multiple regression coefficients obtained by the method of least squares to predict a second-order polynomial model for the EE are presented in Table 4. The corresponding $p$ values of coefficients suggested that $T_{i}$ (reaction time), $S_{\mathrm{r}}$ (substrate molar ratio), $\mathrm{E}_{\mathrm{d}}$ (the amount of enzyme), $T_{i} \times E_{d}$ (substrate molar ratio $\times$ the amount of enzyme), $\mathrm{S}_{\mathrm{r}}{ }^{2}$ (square of substrate molar ratio), $\mathrm{E}_{\mathrm{d}}{ }^{2}$ (square of the enzyme dosage) were significant variables with $p<0.05$. The remaining terms had no significant effects on EE. Furthermore, from Table 4 it can be concluded that EE was influenced 
TABLE 3. Three-level three-factor

Box-Behnken design test results ${ }^{\mathrm{a}}$

\begin{tabular}{lrrrc}
\hline & \multicolumn{3}{c}{ Factors } & \\
\cline { 2 - 4 } Experiment No. & $\mathbf{T}_{\mathbf{i}}$ & $\mathbf{S}_{\mathbf{r}}$ & $\mathbf{E}_{\mathbf{d}}$ & EE $\mathbf{( \% )}$ \\
\hline 1 & -1 & -1 & 0 & 91.75 \\
2 & -1 & 1 & 0 & 94.26 \\
3 & 0 & -1 & -1 & 89.80 \\
4 & 1 & -1 & 0 & 92.61 \\
5 & 0 & 0 & 0 & 95.36 \\
6 & -1 & 0 & 1 & 95.85 \\
7 & 1 & 0 & -1 & 93.68 \\
8 & 0 & 0 & 0 & 94.86 \\
9 & 0 & 0 & 0 & 95.12 \\
10 & 1 & 1 & 0 & 94.82 \\
11 & 0 & 0 & 0 & 94.97 \\
12 & 1 & 0 & 1 & 96.06 \\
13 & 0 & 1 & 1 & 95.05 \\
14 & 0 & 0 & 0 & 95.56 \\
15 & 0 & -1 & 1 & 93.64 \\
16 & -1 & 0 & -1 & 92.81 \\
17 & 0 & 1 & -1 & 93.69 \\
\hline
\end{tabular}

${ }^{\mathrm{a}} \mathrm{EE}$ : efficiency of esterification.

in the following order of significance: $E_{d}>S_{r}>T_{i}$. The second-order polynomial model for the $\mathrm{EE}(\mathrm{Y}, \%)$ is shown in the following equation:

$$
\begin{aligned}
Y & =95.17+0.31 A+1.25 B+1.33 C-0.075 A B-0.16 A C \\
& -0.62 B C-0.13 A^{2}-0.168 \mathrm{~B}^{2}-0.44 C^{2}
\end{aligned}
$$

Where $\mathrm{Y}$ is the $\mathrm{EE} ; \mathrm{A}, \mathrm{B}$, and $\mathrm{C}$ are the independent variables. Here $A$ is $T_{i}, B$ is $S_{r}$, and $C$ is $E_{d}$.

\subsection{Optimization of the reaction}

The optimal conditions for the synthesis of OGEs by Lipozyme 435 were predicted by Design-Expert software. When esterification was catalyzed by $\mathrm{Li}$ pozyme 435 under the optimal conditions $\left(90^{\circ} \mathrm{C}\right.$, $4.52 \mathrm{~h}$, enzyme dosage $2 \mathrm{wt} \%$, oligoglycerol/linoleic acid $=1.59$ in moles), the predicted EE based on the model was $96.15 \%$. The small deviation between the optimal conditions and those local optimal ranges from contour plots (Figure 3 ) is possibly due to the interaction effects of various experimental factors. To further verify the reliability of the regression model, three independent experiments were performed at the predicted optimum conditions, and the actual EE was $95.82 \pm 0.22 \%$, proving the high accuracy of the RSM model used.

\subsection{Production in BCR}

According to Mollenhauer et al. (2010), for a heterogeneous reaction system with high viscosity, a BCR is more suitable than a conventional stirred tank or a fixed bed reactor. In this study, a BCR as shown in Figure 1 was employed to scale-up the synthesis of OGEs, and the bubbling of $\mathrm{N}_{2}$ gas was used as a means of agitation for the reaction mixture. The optimal reaction conditions obtained by RSM were applied to BCR. As expected, the EE achieved was higher than that of a conventional magnetic stirred reactor $(97.23 \%$ vs. $95.82 \%)$. In the

TABLE 4. Analysis of variance (ANOVA) for the fitted quadratic polynomial model

\begin{tabular}{lcrrrrc}
\hline Source & Sum of Squares & $\boldsymbol{d} \boldsymbol{f}$ & Mean Square & F Value & \multicolumn{1}{c}{ Pr $>$ F } & Significant \\
\hline Model & 42.51 & 9 & 4.72 & 84.93 & $<0.0001$ & $*$ \\
$\mathrm{~T}_{\mathrm{i}}$ & 0.78 & 1 & 0.78 & 14.05 & 0.0072 & $*$ \\
$\mathrm{~S}_{\mathrm{r}}$ & 12.55 & 1 & 12.55 & 225.68 & $<0.0001$ & $*$ \\
$\mathrm{E}_{\mathrm{d}}$ & 14.10 & 1 & 14.10 & 253.52 & $<0.0001$ & $*$ \\
$\mathrm{~T}_{\mathrm{i}} \times \mathrm{S}_{\mathrm{r}}$ & 0.023 & 1 & 0.023 & 0.40 & 0.5449 & \\
$\mathrm{~T}_{\mathrm{i}} \times \mathrm{E}_{\mathrm{d}}$ & 0.11 & 1 & 0.11 & 1.96 & 0.2044 & \\
$\mathrm{~S}_{\mathrm{r}} \times \mathrm{E}_{\mathrm{d}}$ & 1.54 & 1 & 1.54 & 27.65 & 0.0012 & $*$ \\
$\mathrm{~T}_{\mathrm{i}}{ }^{2}$ & 0.071 & 1 & 0.071 & 1.27 & 0.2970 & \\
$\mathrm{~S}_{\mathrm{r}}{ }^{2}$ & 11.95 & 1 & 11.95 & 214.85 & $<0.0001$ & $*$ \\
$\mathrm{E}_{\mathrm{d}}$ & 0.83 & 1 & 0.83 & 14.96 & 0.0061 & $*$ \\
Residual & 0.39 & 7 & 0.056 & & & \\
Lack of Fit & 0.063 & 3 & 0.021 & 0.26 & 0.8545 & \\
Pure Error & 0.33 & 4 & 0.082 & & & \\
Cor Total & 42.90 & 16 & & & & \\
$\mathrm{R}^{2}$ & 0.9909 & & & & & \\
Adj. $\mathrm{R}^{2}$ & 0.9793 & & & & & \\
\hline
\end{tabular}

$* \mathrm{P}<0.05$ 

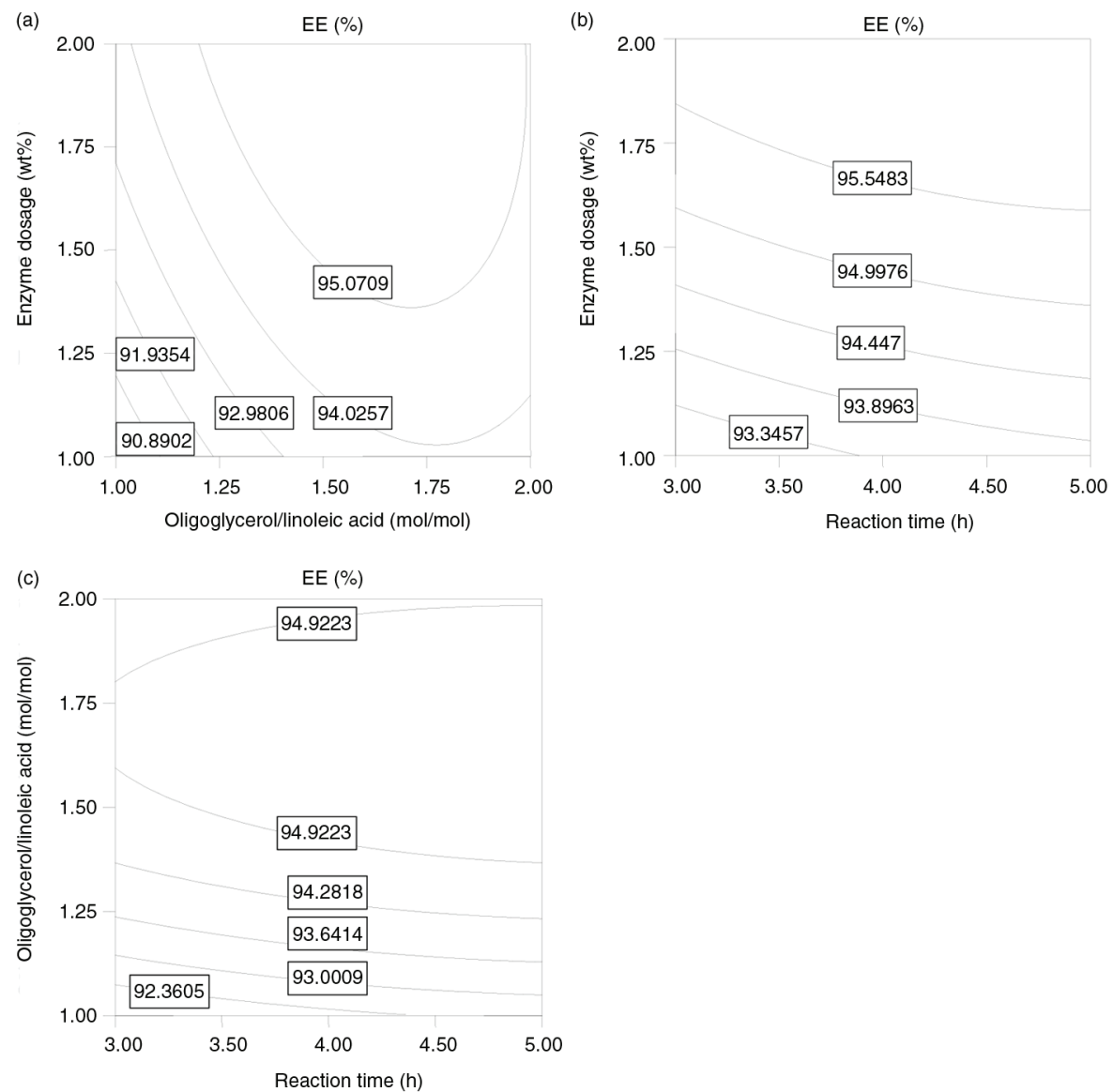

FIGURE 3. Contour plots of interactions among enzyme amounts, oligoglycerol/linoleic acid molar ratio and reaction time. Plot of EE as a function of (a) enzyme dosage and substrate molar ratio for reacting $4.0 \mathrm{~h}$, (b) enzyme dosage and reaction time with a molar ratio of oligoglycerol/linoleic acid at 1.5, (c) oligoglycerol/linoleic acid molar ratio and reaction time with the amount of enzyme fixed at $1.5 \mathrm{wt} \%$.

operational stability test, Lipozyme 435 still maintained $98.2 \%$ of the relative activity after 10 consecutive batch reactions (Figure 4). So in a high viscosity reaction system, agitation by $\mathrm{N}_{2}$ bubbling

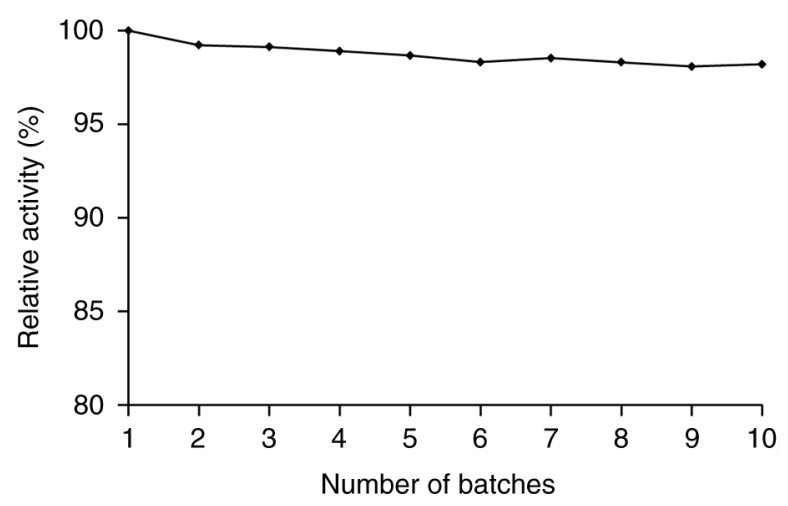

FIGURE 4. The reusability of Lipozyme 435 in bubble column reactor under the optimal conditions $(4.52 \mathrm{~h}$, $90{ }^{\circ} \mathrm{C}, 2 \mathrm{wt} \%$ based on the substrate mass, 1.59:1 of oligoglycerol/linoleic acid molar ratio). can give higher reaction efficiency than by magnetic stirring. That may be because the bubbling of $\mathrm{N}_{2}$ ensured a convective flow field and created an effective interaction in the multiple-phase reaction system to provide a high mass-transferring rate. The excellent operational stability of Lipozyme 435 also benefitted from the gentle agitation and the protective atmosphere provided by $\mathrm{N}_{2}$ bubbling. In comparison, magnetic stirring often mechanically destroys the structure of the enzyme carrier and hence reduces the activity (Mollenhauer et al., 2010). Therefore, production in BCR is a preferred way to achieve a higher yield of OGEs.

\subsection{Composition of the OGE product}

The OGE product obtained under optimal conditions was analyzed by HPLC. As reported by Cassel et al. (2001), the retention time in the reversed-phase HPLC mode increased as more fatty acid chains were attached to polyglycerol. The four groups of peaks (A D in Figure 5) represent the mono-, di-, tri-, and tetraesters of oligoglycerols according to 


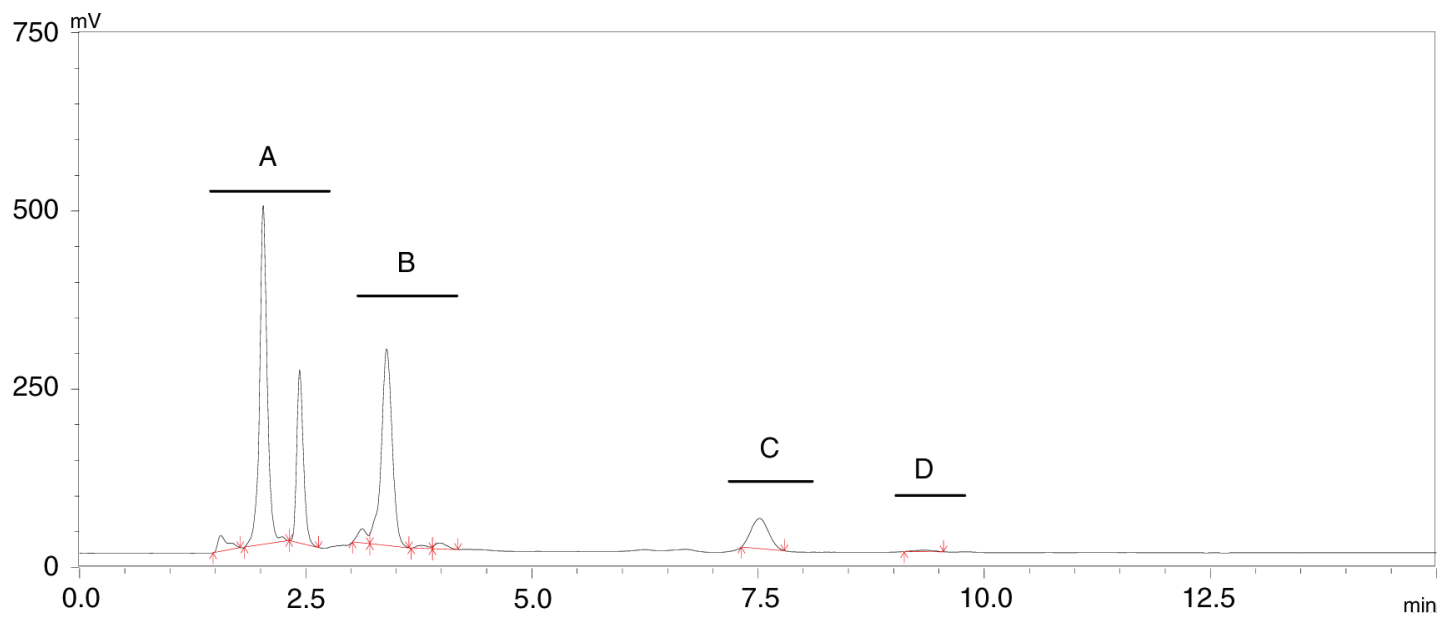

FIGURE 5. HPLC chromatogram of the OGE production catalyzed by Lipozyme 435 under the optimal conditions ( $4.52 \mathrm{~h}, 90^{\circ} \mathrm{C}, 2 \mathrm{wt} \%$ based on the substrate mass, $1.59: 1$ of oligoglycerol/linoleic acid molar ratio). A: monoesters; B: diesters; C: triesters; D: tetraesters of oligoglycerols.

the reversed-phase HPLC theory and the polarity of products (Andersen et al., 2003). By integrating the peak areas in the ELSD chromatogram, it was found that the OGE product contained $56.92 \%$ monoesters, $34.94 \%$ diesters, $7.74 \%$ triesters, and $0.39 \%$ tetraesters of oligoglycerols.

To obtain more details about the OGE product, an ESI-MS spectrum recorded in the positive ion mode was used to analyze the product obtained under optimal conditions (Figure 6). The spectrum contains a wide range of peaks corresponding to the characteristic ions of OGEs. Over 10 OGE species were observed, including glycerol moieties ranging from $n=2 \sim 4$. Based on the ion intensities, the OGE species with $\mathrm{n}=2$ and 3 were the most abundant, which was in agreement with the result of the oligoglycerol composition analyzed by GC. Due to the small vapor pressure difference between PG3 and PG4, after distillation there was still a little PG4 $(4.41 \mathrm{wt} \%)$ remaining in the final products. Thus, OGE species with $n=4$ were also found with low ion intensity. Besides the OGE species as sodium and ammonium adducts, their water adducts and dehydrated forms were also detected in the spectrum (Figure 6). According to Orfanakis et al. (2013), the dehydrated species were not formed as the result of the

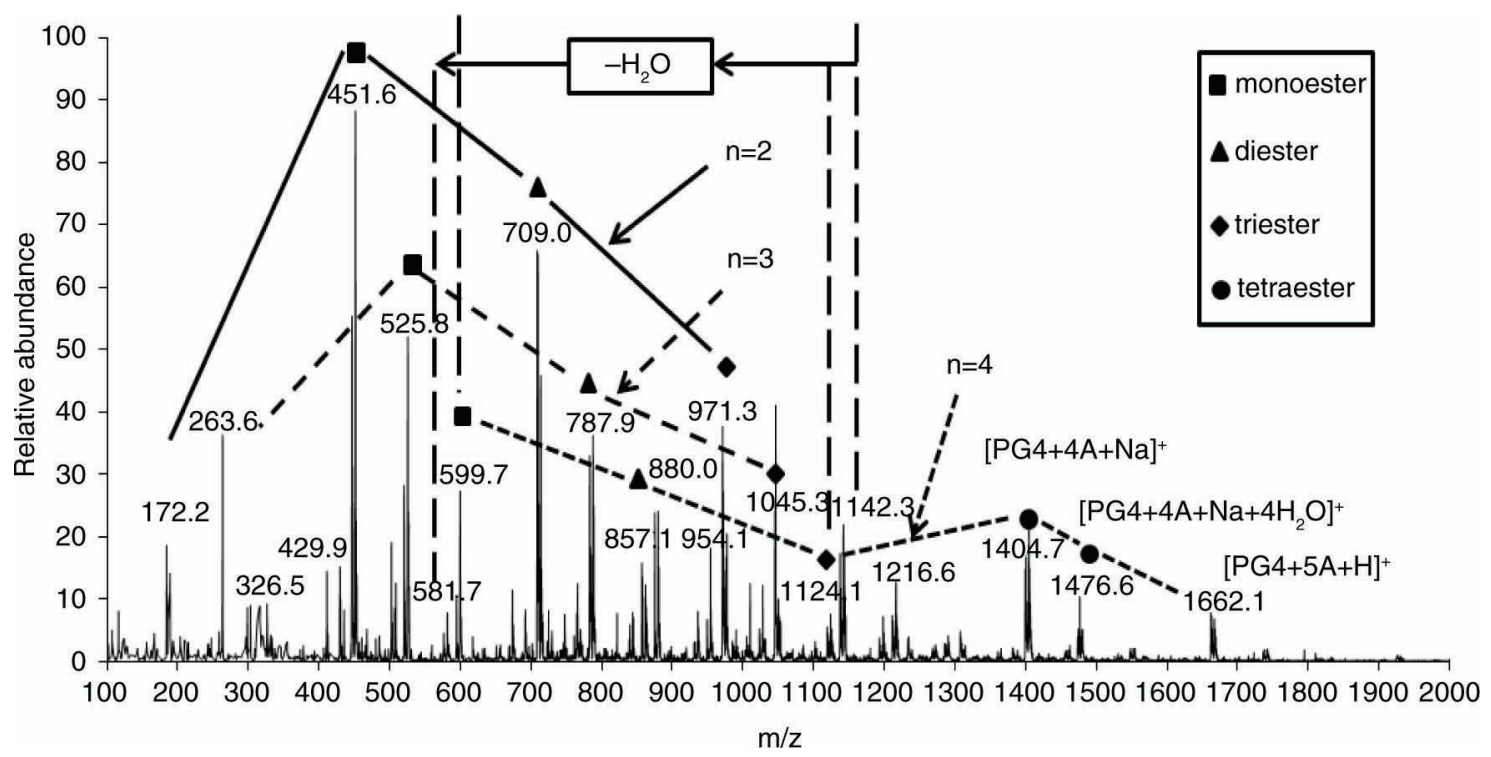

FIGURE 6. ESI-MS spectra of OGEs product in positive ion mode (degree of glycerol polymerization n=2 4). PG4: tetraglycerol; A: Linoleic acid. 
ESI process. It is worth mentioning that the multiple water adducts of $\mathrm{PG} 4$-tetraester $\left(\left[\mathrm{M}+\mathrm{Na}+4 \mathrm{H}_{2} \mathrm{O}\right]^{+}\right.$, $\mathrm{m} / \mathrm{z}=1476.6$ ) were also observed. It indicated that the intermolecular hydrogen bonding was formed between the water molecules and hydroxyl groups due to the high density of the hydroxyl groups on the PG4-tetraester. The water molecules may come from the esterification or from the immobilized enzyme (as stripped in the carrier material).

Linoleic acid appears to react completely as its signal cannot be observed from the spectra. The mono-, di- and triester of oligoglycerol ions all showed high intensities in the spectrum. The intensity of monoesters was greater than the other ions of OGEs. According to the literature (Byun et al., 2007, Liu et al., 2007), the formation of triacylglycerol (TAG) was much less than that of MAG and diacylglycerol (DAG) when sn-1,3-specific lipases were used for the esterification of glycerol with fatty acids. The small amount of TAG might result from the acyl migration to the 2-position in 1,3-DAG, which requires higher amounts of energy to overcome the steric hindrance for further esterification (Liu et al., 2007). This isomerization reaction was considered to be the confined step of TAG synthesis. However, here the amount of triesters was significant. This may be due to the fact that Lipozyme 435 is a nonspecific lipase, thus the acyl donor can be esterified at any available hydroxyl groups in the oligoglycerol and shows higher activities in direct esterification. On the other hand, PG4-tetraester $\left([\mathrm{PG} 4+4 \mathrm{~A}+\mathrm{Na}]^{+}\right.$, $\mathrm{m} / \mathrm{z}=1404.7, \mathrm{~A}=$ Linoleic acid) and PG4-pentaester ions $\left([\mathrm{PG} 4+5 \mathrm{~A}+\mathrm{H}]^{+}, \mathrm{m} / \mathrm{z}=1662.1\right)$ were detected with low intensities, while none of the PG2- and PG3-tetraester ions was observed in the spectra. It seems that the esterification occurred more easily between linoleic acid and PG4 than PG2 or PG3. This is possibly because PG4 has more hydroxyl groups so that the reaction with $\mathrm{PG} 4$ has a less prominent steric hindrance issue. However, it was clear that esterification was incomplete as none of the fully esterified OGE ions was detected.

\section{CONCLUSION}

The biosynthesis of OGEs was investigated using Lipozyme 435 in a solvent-free reaction system. The RSM based on a three-level three-factor BoxBehnken design was used to optimize the reaction parameters. An EE of $96.15 \%$ was achieved under the optimal reaction conditions: $90{ }^{\circ} \mathrm{C}, 4.52 \mathrm{~h}$, enzyme dosage $2 \mathrm{wt}^{\%} \%$ (based on the total substrate mass), oligoglycerol/linoleic acid molar ratio 1.59:1, with no water addition. These conditions were successfully applied in the BCR, and a higher EE was achieved compared with that from the magnetic stirring system. Moreover, the enzyme showed little reduction in activity after reacting for 10 batches. In the large-scale preparation of OGEs at high yield, short reaction time, less consumption of $\mathrm{N}_{2}$ and excellent operational stability of Lipozyme 435 gave the BCR a promising potential for the industrial scale production of OGEs in a high-viscosity heterogeneous reaction system.

Due to the highly complex composition of OGE products, chromatographic analysis methods cannot quantify all these components directly. However, the product compositions were qualitatively determined by ESI-MS. The product analysis indicates that esterification occurred to a significant extent and the reaction product is mainly composed of mono$(56.92 \%)$, di- $(34.94 \%)$ and triesters $(7.74 \%)$ of oligoglycerols, which is preferred for giving good emulsifying properties. To further study the structure of OGEs, the separation and purification of esterification products need to be investigated in depth.

\section{ACKNOWLEDGEMENTS}

The financial support from the Department of Science and Technology of Guangdong Province under Grant 2012B091100035 and 2012A080800013 and the Bureau of Science, Technology and Information of Guangzhou City under Grant 2014Y2-00192, are gratefully acknowledged.

\section{REFERENCES}

Andersen T, Holm A, Skuland IL, Trones R, Greibrokk T. 2003. Characterization of complex mixtures of polyglycerol fatty acid esters using temperature and solvent gradients in packed capillary LC. J. Sep. Sci. 26, 1133-1140. http:// dx.doi.org/10.1002/jssc. 200301538 .

Blasi F, Cossignani L, Simonetti MS, Damiani P. 2007. Biocatalysed synthesis of sn-1,3-diacylglycerol oil from extra virgin olive oil. Enzyme Microb. Tech. 41, 727-732. http:// dx.doi.org/10.1016/j.enzmictec.2007.06.005.

Byun HG, Eom TK, Jung WK, Kim SK. 2007. Lipase catalyzed production of monoacylglycerols by the esterification of fish oil fatty acids with glycerol. Biotechnol. Bioproc. E. 12, 491-496. http://dx.doi.org/10.1007/BF02931345.

Brady C, Metcalfe L, Slaboszewski D, Frank D. 1988. Lipase immobilized on a hydrophobic microporous supports for the hydrolysis of fats. J. Am. Oil Chem. Soc. 65, 917-921. http://dx.doi.org/10.1007/BF02544510.

Cassel S, Chaimbault P, Debaig C, Benvegnu T, Claude S, Plusquellec D, Rollin P, Lafosse M. 2001. Liquid chromatography of polyglycerol fatty esters and fatty ethers on porous graphitic carbon and octadecyl silica by using evaporative light scattering detection and mass spectrometry. J. Chromatog. A 919, 95-106. http://dx.doi.org/10.1016/ S0021-9673(01)00801-9.

Curschellas C, Kohlbrecher J, Geue T, Fischer P, Schmitt B, Rouvet M, Windhab EJ, Limbach HJ. 2013. Foams stabilized by multi lamellar polyglycerol ester self-assemblies. Langmuir 29, 38-49. http://dx.doi.org/10.1021/la3029116.

Charlemagne D, Legoy MD. 1995. Enzymatic synthesis of polyglycerol-fatty acid esters in a solvent-free system. $J$. Am. Oil Chem. Soc. 72, 61-65. http://dx.doi.org/10.1007/ BF02635780.

Chowdary GV, Ramesh MN, Prapulla SG. 2000. Enzymic synthesis of isoamylisovalerate using immobilized lipase from Rhizomucormiehei: a multivariate analysis. Process Biochem. 36, 331-339. http://dx.doi.org/10.1016/S00329592(00)00218-1.

Duan ZQ, Du W, Liu ZH. 2013. Improved synthesis of 1,3-diolein by Novozym 435 mediated esterification of 
monoolein with oleic acid. J. Mol. Catal. B: Enzym. 89, 1-5. http://dx.doi.org/10.1016/j.molcatb.2012.12.003.

Ding ZY, Hao AY, Wang ZN. 2007. Water-in-gasoline microemulsions stabilized by polyglycerol esters. Fuel 86, 597-602. http://dx.doi.org/10.1016/j.fuel.2006.07.028.

Eom TK, Kong CS, Byun HG, Jung WK, Kim SK. 2010. Lipase catalytic synthesis of diacylglycerol from tuna oil and its anti-obesity effect in C57BL/6J mice. Process Biochem. 45, 738-743. http://dx.doi.org/10.1016/j.procbio.2010.01.012.

Freitas L, Perez VH, Santos JC, Castro de HF. 2007. Enzymatic synthesis of glyceride esters in solvent-free system: influence of the molar ratio, lipase source and functional activating agent of the support. J. Brazil. Chem. Soc. 18, $1360-1366$

Griffin WC. 1954. Calculation of HLB values of non-ionic surfactants. J. Soc Cosmet Chem 5, 249-256.

Khemchyan LL, Khokhlova EA, Seitkalieva MM, Ananikov VP. 2013. Efficient sustainable tool for monitoring chemical reactions and structure determination in ionic liquids by ESI-MS. Chemistry Open 2, 208-214. http://dx.doi. org/10.1002/open.201300022.

Liu SC, Zhang CH, Hong PZ, Ji HW. 2007. Lipasecatalysedacylglycerol synthesis of glycerol and n-3 PUFA from tuna oil: optimisation of process parameters. Food Chem.103,1009-1015. http://dx.doi.org/10.1016/j.foodchem. 2006.08.037.

Márquez-Alvarez CM, Sastre E, Pérez-Pariente J. 2004. Solid catalysts for the synthesis of fatty esters of glycerol, polyglycerols and sorbitol from renewable resources. Top Catal. 27, 105-118. http://dx.doi.org/10.1023/B:TOCA. 0000013545.81809.bd

Martin A, Richter M. 2011. Oligomerization of glycerol: a critical review. Eur. J. Lipid Sci. Tech. 113, 100-117. http:// dx.doi.org/10.1002/ejlt.201000386.

Mollenhauer T, Klemm W, Lauterbach M, Ondruschka B, Haupt J. 2010. Process engineering study of the homogenously catalyzed biodiesel synthesis in a bubble column reactor. Ind. Eng. Chem. Res. 49, 12390-12398. http://dx.doi.org/10.1021/ ie101430w.

Ortega S, Bódalo A, Bastida J, Máximo MF, Montiel MC, Gómez M. 2014. Optimized enzymatic synthesis of the food additive polyglycerolpolyricinoleate (PGPR) using Novozym 435 in a solvent free system. Biochem. Eng. J. 84, 91-97. http://dx.doi.org/10.1016/j.bej.2014.01.003.

Ortega S, Máximo MF, Montiel MC, Murcia MD, Arnold G, Bastida J. 2013. Esterification of polyglycerol with polycondensedricinoleic acid catalysed by immobilized Rhizopusoryzae lipase. Bioproc. Biosyst. Eng. 36, 1291-1302. http://dx.doi.org/10.1007/s00449-012-0874-2.

Orfanakis A. Hatzakis E, Kanaki K, Pergantis SA, Rizos A, Dais P. 2013. Characterization of polyglycerolpolyricinoleate formulations using NMR spectroscopy, mass spectrometry and dynamic light scattering. J. Am. Oil Chem. Soc. 90, 39-51. http://dx.doi.org/10.1007/s11746-012-2137-4

Panpipat W, Xu XB, Guo Z. 2012. Towards a commercially potential process: Enzymatic recovery of phytosterols from plant oil deodorizer distillates mixture. Process Biochem. 47, 1256-1262. http://dx.doi.org/10.1016/j.procbio.2012.04.024.

Pan QY, Yang LP, Meng XH. 2013. Optimization of enzymatic synthesis of tricaprylin in ionic liquids by response surface methodology. J. Am. Oil Chem. Soc. 90, 501-509. http:// dx.doi.org/10.1007/s11746-012-2186-8.

Richardson G, Bergenstahl B, Langton M, Stading M, Hermansson AM. 2004. The function of a crystalline emulsifiers on expanding foam surfaces. Food Hydrocolloid 18, 655-663. http://dx.doi.org/10.1016/j.foodhyd.2003.11.003.

Souza MS, Aguieiras ECG, Silva da MAP, Langone MAP. 2009. Biodiesel synthesis via esterification of feedstock with high content of free fatty acids. Appl. Biochem. Biotech. 154, 253-267. http://dx.doi.org/10.1007/s12010-008-8444-4

Saitou K, Homma R, Kudo N, Katsuragi Y, Sato K. 2014. Retardation of crystallization of diacylglycerol oils using polyglycerol fatty acid esters. J. Am. Oil Chem. Soc. 91, 711-719. http://dx.doi.org/10.1007/s11746-014-2466-6.

Shima M, Kobayashi Y, Kimura Y, Adachi S, Matsuno R. 2004. Effect of the hydrophilic surfactants on the preparation and encapsulation efficiency in course and fine $\mathrm{W} / \mathrm{O} / \mathrm{W}$ type emulsions. Colloids Surfaces A: Phys. 238, 83-90. http://dx.doi.org/10.1016/j.colsurfa.2004.02.018.

Shimada Y, Watanabe Y, Sugihara A, Tominaga Y. 2002. Enzymatic alcoholysis for biodiesel fuel production and application of the reaction to oil processing. J. Mol. Catal. B: Enzym. 17, 133-142. http://dx.doi.org/10.1016/S13811177(02)00020-6.

Takatori T, Shimono N, Higaki K, Kimura T. 2004. Evaluation of sustained release suppositories prepared with fatty base including solid fats with high melting points. Int. $J$. Pharm. 278, 275-282. http://dx.doi.org/10.1016/j.ijpharm. 2004.03 .030

Wang Y, Zhao MM, Ou SY, Xie LY, Tang SZ. 2009. Preparation of a diacylglycerol-enriched soybean oil by phosphalipase A1 catalyzed hydrolysis. J. Mol. Catal. B: Enzym. 56, 165-172. http://dx.doi.org/10.1016/j.molcatb.2008.07.008.

Xiao YS, Wang Y, Zhang GW. 2012. Optimization of preparation of polyglycerol fatty acid ester catalyzed by Phospholipase A1 in a solvent free system using response surface methodology. Sci. Tech. Food Indus. 33, 191-194.

Yamagata Y, Iga K, Ogawa Y. 2000. Novel sustained-release dosage forms of proteins using polyglycerol esters of fatty acids. J. Control Release, 63, 319-329. http://dx.doi.org/10.1016/ S0168-3659(99)00206-0.

Zou L, Akoh CC. 2013. Identification of tocopherols, tocotrienols, and their fatty acid esters in residues and distillates of structured lipids purified by short-path distillation. $J$. Agric. Food Chem. 61, 238-246. http://dx.doi.org/10.1021/ jf304441j.

Zhong NJ, Gui ZY, Xu L, Huang JR, Hu K, Gao YQ, Zhang X, Xu ZB, Su JY, Li B. 2013. Solvent-free enzymatic synthesis of 1,3-diacylglycerols by direct esterification of glycerol with saturated fatty acids. Lipids Health Dis. 12, 12-65. 